Kok M., H. Massinen, I. Moshnikov, E. Penttilä, S. Tavi \& L. Tuomainen (toim.) 2019. Pidetään kielet elävinä - Keeping languages alive - Piemmö kielet elävinny. AFinLAn vuosikirja 2019. Suomen soveltavan kielitieteen yhdistyksen julkaisuja n:o 77. Jyväskylä. s. 19-41.

Leena Niiranen

UiT - Norges arktiske universitet

\title{
Kveenien omakielisen lukemisen traditio ja sen merkitys kielen säilymiselle
}

This article examines the reading habits of the Kven minority in Norway. Historical sources note that Kvens were able to read in Finnish already in the $18^{\text {th }}$ century. Up to the middle of the $19^{\text {th }}$ century, most books printed in Finnish were religious texts written in Old Literary Finnish. During the Early Modern Finnish period (1820-1870), more secular literature appeared. Although the Kvens mostly read religious texts, they also read some secular literature. Kvens would gather to read religious books written in Old Literary Finnish in homes following a religious tradition of repetitive reading. It is quite probable that this reading practice had an impact on Kven language maintenance. Extensive reading refers to the reading of many different types of texts. In Finland, extensive reading expanded among common people during the Early Modern Finnish period. By contrast, extensive reading among Kvens was most often conducted in Norwegian.

Keywords: reading activity, language maintenance, Kven

Asiasanat: lukeminen, kielen ylläpito, kveeni

VERTAISARVIOITU

KOLLEGIALT GRANSKAD

PEER-REVIEWED

www.tsv.fi/tunnus 


\section{Johdanto}

Kveenin kieli sai virallisen vähemmistökielen aseman Norjassa 2005, jolloin kveeniä alettiin myös kehittää kirjallisen ilmaisun kieleksi. Jo 2004 ilmestyi ensimmäinen kveeninkielinen romaani, Alf Nilsen-Børsskogin Kuosuvaaran takana, jonka jatko-osat ilmestyivät 2007-2018. Nilsen-Børsskog julkaisi myös useita runoteoksia. Kveeniksi kirjoitettiin oppimateriaaleja, kveenin kielen opetus käynnistyi Tromssan yliopistossa, ja vuonna 2014 ilmestyi Eira Söderholmin kveenin kielen kielioppi.

Tutkijat, jotka keräsivät aineistoa kveenimurteista 1970-luvulla, totesivat, että vaikka kveeni oli säilynyt puhuttuna vähemmistökielenä, oli kveenien kouluopetus jo niin kauan ollut vain norjankielistä, että tämän seurauksena kveenien kirjallisen sivistyksen kieli oli norja (Lindgren 2009: 114). Kveenit ovat kuitenkin olleet kosketuksissa myös suomen kirjakieleen, erityisesti vanhalla kirjasuomella kirjoitettuun uskonnolliseen kirjallisuuteen, mutta myös varhaisnykysuomeksi ja nykysuomeksikin kirjoitettuihin teksteihin. Tässä artikkelissa pyrin tuomaan esille, millaisia tekstejä kveenit lukivat historiallisten lähteiden perusteella.

Lukemis- ja kirjoittamistaito liitetään usein vähemmistökielen säilymiseen. Erityisesti ajatellaan, että omakieliset kirjalliset taidot ovat välttämättömiä, kun vähemmistökieltä pyritään elvyttämään (Grenoble \& Whaley 2006: 102-103). Kielen elvytys edellyttää usein kielen opetusta myös sellaisille, jotka eivät ole sitä aiemmin osanneet, ja kielenopetusta on vaikea toteuttaa ilman, että elvytettävää kieltä on kirjakielistetty. Pawels (2016: 132) toteaa, että kirjalliset taidot tukevat kielen säilymistä, koska niiden avulla on mahdollista lisätä kielellisten resurssien määrää. Pohdin tässä artikkelissa myös sitä, miten kveenien omakieliset kirjalliset taidot mahdollisesti vaikuttivat siihen, että kveeni säilyi vähemmistökielenä Norjassa läpi vuosisatojen norjalaistamispolitiikasta huolimatta. Keskityn lukemiseen ja sen merkitykseen kielen säilymiselle.

Esitän lyhyen katsauksen kveeniasutusten syntymisestä luvussa 2. Luvussa 3 esittelen ensin lukutaitoa eri aikakausina, ja erityisesti pyrin tuomaan esille sen, miten lukutaito kehittyi tavallisen kansan keskuudessa Suomessa aikana, jolloin kveenit muuttivat Norjaan. Esittelen myös lukemisen erilaisia kulttuureja ja kulttuurien muuttumista. Luku 4 esittelee artikkelissa käytetyn metodin. Luvussa 5 tuon esiin kirjallisuutta, jota kveenit ovat eri aikoina lukeneet. Luvussa 6 pohdin kveenien lukemistraditioita suhteessa erilaisiin lukemiskulttuureihin ja luvussa 7 erityisesti sitä, miten kveenien lukemistraditiot ovat vaikuttaneet kielen ylläpitoon. Luku 8 on yhteenveto artikkelista. 


\section{Kveeniasutukset ja niiden synty Norjassa}

Ensimmäiset kveenit muuttivat Pohjois-Norjaan jo 1500- ja 1600-luvuilla, mutta varsinaisia asutuksia syntyi vasta $1700-$-luvulla erityisesti nykyisten Länsi-Finmarkun ${ }^{1}$ ja Tromssan läänien alueille (Ryymin 2004: 3-4).

Kveenit saapuivat Norjaan 1700-luvulla erityisesti Tornionlaakson suomenkielisiltä alueilta sekä Ruotsin että Suomen puolelta. 1800-luvulla Norjaan muutettiin myös muualta Pohjois-Suomesta. Norjassa näiden asukkaiden samoin kuin heidän kielensä nimitys on ollut kveeni. ${ }^{2}$ (Niemi 1977: 21, 31; Eriksen \& Niemi 1981: 30-32.) Norjaan saatettiin muuttaa pakoon sotia ja sotaväenottoja; esimerkiksi Alattioon saapui 1700-luvun alussa miehiä, jotka olivat paossa suurta Pohjan sotaa (Henninen 1972: 79-80). Norjaan tultiin pakoon myös huonoja satovuosia. Jäämeri oli avoin myös talvella, ja kalastus tarjosi ravintoa silloinkin, kun viljasato pohjoisilla alueilla ei onnistunut. 1700-luvulla muuttaneet kveenit aloittivat maanviljelyksen, ja heitä pidetäänkin maanviljelyksen pioneereina Pohjois-Norjassa. (Niemi 1977: 2.)

1800-luvulla kveenejä saapui erimerkiksi Kaavuonon kuparikaivokselle, joka oli toiminnassa 1826-1909. Lähellä Alattiota sijaitseva Kaavuonon kuparikaivos oli englantilaisten perustama, ja se oli aikoinaan Finmarkun suurin asutuskeskus. (Hiss 2017: 701-702.) 1800-luvun kuluessa kveenit kuitenkin alkoivat siirtyä yhä useammin erityisesti Itä-Finmarkkuun.

Kveenisiirtolaisuus Pohjois-Norjaan lisääntyi erityisesti 1860-luvulla, jolloin Suomessa mm. vallitsivat nälkävuodet. Itä-Finmarkkuun keskittyvä muuttoliike sai aikaan sen, että esimerkiksi Vesisaareen muutti niin paljon suomalaisia, että kaupunki sai nimekseen "kveenien pääkaupunki". Vesisaari toimi myös välietappina monille, jotka jatkoivat sieltä matkaansa Amerikkaan. (Niemi 1977: 29; Ryymin 2004: 83-84.)

\section{$3 \quad$ Lukutaidon kehittyminen ja lukemisen kulttuurit}

Lukemisen kulttuurissa on tapahtunut muutoksia vuosisatojen aikana. Meidän aikakaudellemme tyypillinen lukeminen, jossa luetaan paljon erilaisia tekstejä, edellyttää paitsi lukutaitoa, myös saatavilla olevia tekstejä. Mäkinen (1997) kuvaa modernin lukuhalun tuloa Suomeen. Se levisi tavallisen kansan keskuuteen kansakoulujen pe-

$1 \quad$ Kveeninkielisistä paikannimistä Norjassa käytän muotoja, jotka ovat käytössä Norjan kielineuvoston (Norsk språkråd) ylläpitämillä sivuilla "kvenskestedsnavn.no" siinä tapauksessa, että nimi on löydettävissä näiltä sivuilta.

2 Kveeni-nimitys on peräisin jo 800-luvulta, jolloin Ottar-niminen norjalainen kirjoitti selostuksen pohjoisten alueiden asukkaista Englannin kuningas Alfredille. Kveenit olivat Pohjanlahden perukassa asuvaa väestöä. (Forsgren \& Minken 2019.) Koska saamelaisista käytettiin Norjassa aikaisemmin usein nimitystä "finn" vrt. Finnmark, kveeni-nimityksen merkitys oli myös erottaa nämä ryhmät toisistaan. (Berg-Nordlie 2018.) 
rustamisen jälkeen 1800-luvun jälkipuoliskolla, jolloin myös eri tekstilajeja edustavia suomenkielisiä tekstejä alettiin laajemmin painaa ja levittää. Kirjastolaitos lisäsi Suomessa lukemista, samoin suomenkielisten sanomalehtien syntyminen ja niiden levikin lisääntyminen. Fennomaanien panos modernin suomen kielen kehitykselle oli tärkeää kaikilla näillä alueilla. (Leino-Kaukiainen 1989: 329-343; Häkkinen 1994: 11-19.)

Tekstien lisääntyessä siirryttiin suomen kielelläkin yhä enenevässä määrin ekstensiiviseen lukemiseen, joka tarkoittaa, että luetaan paljon erilaisia tekstejä. Lukemisen päämääräksi tuli myös huvi tiedon hankkimisen lisäksi. Aikaisempi lukemisen kulttuuri, toistolukeminen, oli kuulunut erityisesti uskonnollisen kirjallisuuden lukemisen traditioon. Tärkeitä uskonnollisia tekstejä luettiin moneen kertaan, toisaalta lukeminen rajoitettiin vain joihinkin teksteihin. (Mäkinen 1997: 29, 36-37.) Laineen (2017: 158-166) mukaan kuitenkin sekä intensiivinen eli toistolukeminen että ekstensiivinen lukeminen kuuluivat myös uskonnolliseen lukemiseen jo esimodernina aikana. Hänen mukaansa molemmat lukutavat ovat eläneet rinnakkain, ja ekstensiivistä lukutapaa alettiin käyttää Suomessa jo 1700-luvun lopulla.

Lukemisen opettaminen kansalle ennen kansakoulujärjestelmän syntyä oli luterilaisen kirkon vastuulla. Päämääränä oli opettaa ihmisille kristinuskon pääkappaleet. Lukemaan oppiminen perustui tehokkaaseen sosiaaliseen kontrolliin ja pakkoon. Jo 1686 Ruotsin valtakunnassa säädettiin kirkkolaki, jonka perusteella lukemisen osaaminen oli edellytys sekä naimisiin pääsylle että ehtoollisella käymiselle. (Mäkinen 1997: 61-64.)

Tuottiko pakkolukemisen vaatimus ihmisille lukutaidon, johon sisältyi muutakin kuin katekismuksen ulkoa oppimista? Suomalaisten lukutaidon arviointi ennen kansakoulujen tuloa perustuu pappien lukukinkereillä tekemiin muistiinpanoihin. On arveltu, että jo 1720-30-luvuilla 20-30 \% talonpoikaisesta väestöstä ja 1740-luvun lopulla puolet väestöstä osasi lukea (Tommila 1986: 178). Vaikka lasten lukemaan opettaminen oli vanhempien velvollisuus, myös kirkko järjesti opetusta. Jo Gezelius-piispojen aikana lukutaito oli lisääntynyt. Isoviha merkitsi taantumaa, mutta rauhan palattua kirkko tehosti lukemaan opettamista 1700-luvun kuluessa esimerkiksi aloittamalla rippikoulut. (Laasonen 2000: 179-181, 246-250.) Kirkon päämääränä oli vain lukutaidon, ei kirjoitustaidon opettaminen. Kirjoitustaito oli tärkeää usein vain tietyissä ammateissa, minkä takia sen yleistä opettamista ei pidetty tärkeänä. Kuitenkin aktiivinen luku- ja kirjoitustaito lisääntyivät Suomessa jo ennen kansakoulujen leviämistä, 1840-50-luvuilla. (Tommila 1986: 178.)

Omaehtoinen lukeminen kansan parissa laajeni myös pietismin vaikutuksesta. Pietismi syntyi Saksassa 1600-luvulla ja saapui Suomeen 1600-luvun lopulla.1700-luvun puolivälissä se levisi kansan keskuuteen. Reformaation jälkeen oli syntynyt puhdasoppisuutta korostava kristillisyys, jota pietistit arvostelivat, koska se ei ollut kiinnostunut yksilön uskonnollisuudesta. Pietismi sen sijaan korosti yksilön henkilökohtaista uskonelämää. Se teki eron tapakristillisyyden ja omakohtaisen us- 
konelämän välillä. (Laasonen 2000: 185-194, 268-279.) Hartauskirjallisuuden lukeminen liittyi omakohtaiseen kristillisyyteen, ja pietistit pitivätkin tärkeänä kodeissa pidettäviä hartaudenharjoituksia. Pietistinen lukeminen oli välivaihe traditionaalisesta toistolukemisesta ekstensiiviseen lukemiseen, koska lukeminen perustui omaehtoiseen haluun, ei kirkon taholta tulleeseen pakkoon. (Mäkinen 1997: 37-38.)

Kun kveenit siirtyivät uuteen valtakuntaan, he veivät mukanaan entiset tapansa, joihin muun muassa kuului uskonnollisten tekstien lukeminen suomeksi. Millaisia lukemistraditioita esiintyi alueilla, joilta kveenit siirtyivät Norjaan? Kirkollista lukemiskulttuuria Pohjois-Ruotsissa ja -Suomessa 1700-luvulla on tutkittu saamelaisten keskuudessa. Anderzén (1996: 7-14) kuvaa Kemin ja Tornion Lapeissa vallinnutta kylärukoustraditiota (ruotsiksi "byabön"). Koska välimatkat olivat pitkiä, kirkonkäynnin sijasta järjestettiin kylissä yhteisiä uskonnollisia tapaamisia, joissa saarnan asemesta luettiin postillaa eli saarnakokoelmaa. Postilla sisältää kirkkovuoden tekstit selityksineen (Häkkinen 1994: 93). Lukijana oli lukutaitoinen maallikko, lukkari tai katekeetta. Saamelaisten keskuudessa käytettiin suomenkielisiä kirjoja.

Välitalo (1970: 20-35) kuvaa vastaavanlaisia kyläkuntien yhteisiä kyläjumalanpalveluksia Muonionlaaksossa. Hänen tutkimuksensa perustuu suulliseen perimätietoon. Kokouksia johti lukutaitoinen maallikko. Luettavia tekstejä olivat epistola- ja evankeliumitekstit sekä postilla. Lisäksi laulettiin virsiä. Vaikka tiedot kylärukousten alkamisesta Muonionlaakson kylissä ovat vasta 1800-luvulta, Välitalo arvelee erilaisiin kirjallisiin dokumentteihin perustuen, että tapa on peräisin jo varhaisemmalta ajalta. Välitalon (1970: 23-24) mukaan kylärukoustapa jatkui edelleen pietistisessä liikkeessä nimeltä wiklundilaisuus, joka vaikutti Tornionlaaksossa 1770-luvulla. Muitakin pietistiä liikkeitä esiintyi, esimerkiksi lukijaisuus. Välitalo toteaa näiden liikkeiden lisänneen lukuharrastusta ja kirjojen hankkimista. Myös Paunonen (2018: 17) mainitsee kylärukoukset tilaisuuksina, joissa Ruotsin Tornionlaaksossa luettiin uskonnollista kirjallisuutta suomeksi.

Kveenien yhteyksistä pietismiin ei ole olemassa tutkimusta, mutta kveenit olivat yhteydessä mm. Tornioon koko 1700-luvun esimerkiksi sieltä Ruijaan matkustavien kauppiaiden välityksellä (Henninen 1972: 93). Varhaisia pietistisiä vaikutteita esiintyi Torniossa jo 1600-luvun lopulla (Vuolasto 2011: 206, 227). Vaikutteet saattoivat tulla myös Ruijaan muuttavien kveenin mukana.

Uskonnollista lukemista harrastettiin myös lestadiolaisessa liikkeessä. Se levisi Ruijaan Ruotsin Pajalasta, jossa Lars Levi Laestadius toimi kirkkoherrana, jo 1840-luvulta lähtien sekä saamelaisten että kveenien välityksellä. Liike kasvoi 1870-80-luvuilla. Norjassa lestadiolaisuus sai vahvan aseman erityisesti vähemmistöjen keskuudessa, vaikka liikkeeseen kuului myös norjalaisia. (Aadnanes 1986: 32, 51, 59, 89-90.) Lestadiolaisessa liikkeessä suomen kielellä oli erityinen asema "pyhänä kielenä" (Elenius 2001: 402; Larsen 2012: 309). 
Suomen kirjakielen käyttäminen kuului 1800-luvun puoliväliin asti pääasiassa vaikkakaan ei yksinomaan - uskonnollisiin yhteyksiin (Pulkkinen 1972: 83; Häkkinen 1994: 96-97). Kirjakielen käyttö vaikuttaa kielen ylläpitoon erityisesti silloin, kun lukeminen ja mahdollisesti myös kirjoittaminen kuuluvat kieliyhteisön jäsenten kielellisiin käytänteisiin. Termi kielellinen käytänne (practice) viittaa toistuvaan toimintaan, jossa kielenkäytöllä on keskeinen sija (Pennycook 2017: 139).

Uskonnollisten tapahtumien yhteydessä kieltä käytetään eri tavoin, ei vain uskonnollisissa rituaaleissa, vaan myös osana sosiaalista kanssakäymistä, ja siksi uskonnolla on merkitystä kielen säilymiselle (Pauwels 2016: 135-138).

Esitellessäni kveenien lukemaa kirjallisuutta käsittelen myös kysymystä siitä, millaiseen kontekstiin kveenien lukeminen voidaan sijoittaa. Tämän lisäksi tuon esiin erilaisia lukutapoja, eli kiinnitän huomiota siihen, onko tekstejä luettu ääneen vai hiljaa, jos tästä on saatavissa tietoa lähteiden perusteella.

Kveenien lukemista tuon esiin myös kirjahistorian esittämien kysymysten valossa. Kirjahistoria tutkii kirjojen painamista ja levikkiä, lukemista eri maantieteellisillä alueilla, lukijoita ja kirjojen omistajia (Laine 2018). Kveenit myös kirjoittivat omaa kieltään (esim. Maliniemi 2010). En kuitenkaan käsittele kveenien kirjoittamia tekstejä, vaan keskityn pelkästään lukemiseen.

\section{Lähteet}

Tarkastelen erilaisten kirjallisten ja arkistolähteiden perusteella, millaisia suomeksi kirjoitettuja kirjoja oli levinnyt kveenien keskuuteen. Olen yrittänyt löytää lähteissä mainituista kirjoista seuraavat tiedot: kirjoittaja, mahdollisesti kääntäjä, kustantaja, painovuosi ja uusintapainokset. Olen myös merkinnyt ylös kirjan omistajan Norjassa, silloin kun tällainen tieto on ollut saatavilla. (Vrt. Laine 2018.) Uusintapainosten määrä kertoo kirjan suosiosta Suomessa. Olen lisäksi pyrkinyt etsimään tietoja kirjan levikistä erityisesti Pohjois-Suomessa. Olen ryhmitellyt kirjoja tekstilajien perusteella. Päätekstilajit ovat uskonnollinen ja maallinen kirjallisuus, joissa molemmissa esiintyy myös alaryhmiä. Erikseen käsittelen kveenien koulukirjoja. Tutkimukseni on kvalitatiivista, eli en esitä lukumääriä eri genreihin kuuluvista kirjoista. Genrejako tuo kuitenkin esiin ainakin karkean kuvan siitä, millaista kirjallisuutta kveenit näyttävät eniten lukeneen. Silti kveenit ovat voineet lukea muitakin kuin lähteissä esiintyneitä kirjoja. Tietojen hankkimista kveenien kirjoista vaikeuttaa $\mathrm{mm}$. se, että toisen maailmansodan aikana monet juuri niistä alueista, joilla kveenit asuivat, poltettiin. Samalla hävisi myös suuri osa kirjallisuutta, jota kveenit olivat lukeneet.

Jo Jacob Fellman, joka toimi pappina Utsjoella 1819-1831 ja kävi tutustumassa myös kveeneihin Norjassa, mainitsee nimeltä joitakin teoksia, joita kveenit lukivat kokoontumisissaan (Fellman 1978: 101). Monet maininnat kveenien lukemasta kirjallisuudesta ovat peräisin kuitenkin vasta Samuli Paulaharjulta (1928, 1935), joka 
1920-30-luvuilla kiersi Ruijaa ja kokosi kansanperinnemateriaalia kveenien parista. Paulaharju on usein merkinnyt muistiin paitsi kirjan myös sen omistajan. Paulaharjun merkitys lähteenä korostuu vielä senkin vuoksi, että hänen tietonsa ovat peräisin ajalta ennen toista maailmansotaa. Paulaharjun kirjojen lisäksi olen löytänyt tietoja myös Paulaharjun arkistosta, jota säilytetään Suomalaisen Kirjallisuuden Seurassa.

Matti A. Sainio (1949) on laatinut Norjassa 1860-1929 ilmestyneistä suomenkielisistä painotuotteista bibliografian. Erityisesti Norjan kouluissa 1800-luvulla käytettyjen oppikirjojen osalta olen käyttänyt lähteenä myös Helge Dahlin (1957) tutkimusta. Olen etsinyt tietoja kveenien kirjoista myös digitaalisesta Historiallisesta sanomalehtikirjastosta (Historiallinen sanomalehtikirjasto).

Käytettyjen lähteiden perusteella ei ole mahdollista kuin aivan ylimalkaisesti arvioida, miten laaja levikki suomenkielisillä kirjoilla oli kveenien parissa. Pyrkimyksenä on pääasiassa kartoittaa kveenien lukemia kirjoja. Kirjojen levikkiä Pohjois-Suomessa olen tutkinut Suomalaisen Kirjallisuuden Seuran ylläpitämästä Henrik-tietokantasta, joka kertoo kirjojen omistuksesta Suomessa vuoteen 1809. Tietokanta esittelee kirjojen levikkiä suomalaisissa kaupungeissa, mm. Torniossa. Myös Norjan museoiden nettisivulta (Digitaltmuseum) voi löytää kirjoja, joita kveenit ovat lukeneet.

\section{$5 \quad$ Kveenien lukema kirjallisuus}

Jo 1700-luvun alusta on tietoja siitä, että kveenien joukossa oli henkilöitä, jotka osasivat lukea. Thomas von Westen tapasi matkallaan Finmarkkuun vuonna 1716 Alattiossa kveenejä, jotka omistivat kveeninkielisiä kirjoja ja lukivat niitä. (Hammond 1787: 254.) Kyseessä ilmeisesti olivat vanhalla kirjasuomella kirjoitetut teokset. Thomas von Westen on tunnettu "saamelaisten apostolina", joka vuosina 1716-23 teki kolme lähetysmatkaa Pohjois-Norjaan. Von Westen oli varhainen pietisti, jonka mukaan saamenkielisille tulisi tarjota kirkollisia palveluksia omalla kielellä (Weihe 2018).

Myöhempi maininta siitä, että kveenit Alattiossa lukivat omakielisiä kirjoja on vuodelta 1740, jolloin Alattion kveenit kokoontuivat lukemaan "karjalankielisiä" kirjoja (Nielsen 1990: 274), joilla myös viitataan suomenkielisiin kirjoihin. Nielsen arvelee, että Alattion kveeneillä oli omakielisiä uskonnollisia kokoontumisia koko 1700-luvun ajan. Jacob Fellman (1978: 61) mainitsee, että kveenit Pulmangissa lukivat suomenkielistä uskonnollista kirjallisuutta vuonna 1821. Fellmanin (1978: 101) mukaan Norjan suurin kveeniyhteisö 1800-luvun alkupuolella oli Alattiossa. Siellä kokoonnuttiin sunnuntaisin lukutaitoisen henkilön johdolla lukemaan postillaa. Esimerkiksi vuonna 1828 Alattiossa vieraileva torniolainen opiskelija johti hartaudenharjoituksia. 
Olen seuraavassa esittelyssä jakanut kveenien lukeman kirjallisuuden uskonnolliseen kirjallisuuteen, koulukirjoihin ja maalliseen kirjallisuuteen.

\subsection{Uskonnollinen kirjallisuus}

Kveenien lukemaan suomenkieliseen kirjallisuuteen kuului runsaasti erilaista uskonnollista kirjallisuutta. Suomeksi julkaistiin Ruotsin vallan aikana 1543-1808 vain 174 ensipainosta ${ }^{3}$, joista suurin osa oli käännettyä uskonnollista kirjallisuutta. 1800-luvun puoliväliin asti uskonnollinen kirjallisuus olikin enemmistönä suomeksi julkaistusta kirjallisuudesta. (Leino-Kaukiainen 1989: 339.)

Eräs varhaisimmista suomeksi julkaistuista teoksista, joka on löytynyt myös Ruijasta, on vuoden 1642 Raamattu eli ns. Kristiinan Raamattu. Nimensä Raamattu sai siitä, että se oli omistettu kuningatar Kristiinalle (Laasonen 2000: 43). Vesisaaresta 1926 löytyneellä Raamatulla oli Paulaharjun (1928: 459-460) mukaan kova kohtalo: Ristiinan Raamattua käytettiin Vesisaaressa "rönsoopapaperina" eli mäntysuovan käärepaperina, kunnes joku kveenivaimo käski lopettaa Raamatun repimisen. Vuoden 1642 Raamattua painettiin vain 1200 kappaletta, ja niistäkin vain 800 saatiin Suomeen (Laasonen 2000:43). Onkin ihmeellistä, että yksi näistä kirjoista oli kulkeutunut Ruijaan. Muistiinpanoissaan Paulaharju vahvistaa, että kyse todella oli kantensa menettäneestä vuoden 1642 Raamatusta, ja että hän ehdotti kirjan siirrettäväksi kirjastoon (Paulaharjun arkisto, KRA S 113: 1940: 37900). Raamattu katosi luultavasti sodan aikana, kun Finmarkun kirjasto, johon se todennäköisesti oli siirretty, tuhoutui (Sainio 1949: 6).

Muita Paulaharjun (1928) mainitsemia Raamatun painoksia ovat Helsingissä vuonna 1852 painettu ja Porvoossa vuonna 1853 painettu Raamattu (mts. 459-460). Kalle Moilanen Vesisaaressa puolestaan omisti Raamatun vuodelta 1878 (mts. 461). Alattiolaisen Aaronin Mikon jäämistöön kuului myös Raamattu (mts. 81).

Postillat eli saarnakokoelmat olivat myös suosittua lukemista aikoinaan, ja niistä saatettiin toimittaa useita painoksia. Jo Fellman (1978: 101) mainitsee kveenien lukemaan kirjallisuuteen Altenissa eli Alattiossa kuuluneen Ericus Ericin, Frankin ja Wegeliuksen postillat 1800-luvun alkupuoliskolla. Näistä etenkin Wegeliusta luettiin ahkerasti. Turun piispan Ericus Ericin eli Sorolaisen (n. 1546-1625) kaksiosainen postilla oli ensimmäinen suomenkielinen saarnakokoelma, joka ilmestyi jo vuosina 1621-25. Postilla oli tarkoitettu paitsi pappien, myös maallikoiden käyttöön. (Heininen ym. 1997: 168.)

3 Laine (2017) esittää huomattavasti korkeamman ensipainosten määrän: 1788 vuoteen 1800 mennessä. Mukana on kaikki Pippingin (1856-1857) kirjaluettelossa esiintyneet tekstit, eli myös pienpainatteet kuten asetukset ja kuulutukset. Leino-Kaukiaisen luku viittaa kirjoihin. 
Ericus Ericin postilla kuuluu varhaisen puhdasoppisuuden kauteen, kun taas Frankin ja Wegeliuksen postillat kuuluvat pietistiseen traditioon. Johannes Wegelius nuoremman kaksiosainen postilla Se Pyhä Evankeliumillinen Walkeus ilmestyi vuosina 1747-49. Wegeliuksen postillan lähteenä ovat osittain olleet pietismin perustajana pidetyn Spenerin saarnat, vaikka Wegelius ei tästä lähteestään mainitsekaan mitään. Ensimmäisen painoksen esipuhe on allekirjoitettu Torniossa vuonna 1742. (Tiililä 1961: 110-113.)

Wegeliuksen postillasta otettiin kaikkiaan neljä painosta, viimeinen 1800-luvun lopulla. Tiiliäa (1961: 147) mainitsee, että Wegeliuksen postillan tiedetään levinneen yksinomaan Tornionlaaksoon 1800-luvun alkuun mennessä ainakin 200 kappaleena. Fellmanin lisäksi myös Paulaharju esittelee Wegeliuksen postillan kveenien lukemistona useamman kerran, mm. Pyssyjoella Oulan Jounin omistuksessa ja Lemmijoella Raution Riitan omistuksessa (Paulaharju 1928: 126, 140).

Frankin postilla on August Herman Francken alunperin saksaksi kirjoittama kaksiosainen postilla, joka käännettiin ruotsin välityksellä suomeksi ja painettiin vuosina 1780 ja 1781. August Herman France oli Hallen pietisti, jonka kirjoihin suomalaiset karoliinit eli Kaarle XII:n sotilaat tutustuivat jouduttuaan Venäjälle vangeiksi Pultavan taistelun jälkeen. Kirjoja tuotiin kotiin ja käännettiin ruotsiksi 1720-luvulla. (Laasonen 2003: 108.) Vaikka hallelainen pietismi levisi aluksi lähinnä upseerien ja sivistyneistön keskuuteen, se sai jalansijaa vähitellen myös kansanherätyksen piirissä. Francken suomen-, ruotsin- tai saksankielisen postillan omistajia oli perunkirjojen mukaan useammassa kaupungissa Suomessa jo 1700-luvun lopulta lähtien (Henrik-tietokanta). Esimerkiksi Oulussa suomenkielinen Francken postilla kuului useamman henkilön jäämistöön jo 1700-luvun lopulla. Torniossa Francken postilla esiintyi piika Maria Johansdotter Partasen perunkirjoituksessa vuonna 1803 ja työmiehen vaimo Hierta Walborg Larsdotterin perunkirjoissa vuonna 1784, mikä kertoo siitä, että kirjoja saattoivat omistaa jo 1700-luvulla muutkin kuin vain sivistyneistöön kuuluvat. Viimeistään 1800-luvun alkupuolella Francken postilla on siis Fellmanin (1978: 101) mukaan löytänyt tiensä jo Alattioon asti.

Muita Paulaharjun mainitsemia postilloita, joita kveenit omistivat ja lukivat, ovat Nohrbergin, Lutherin ja Laestadiuksen postillat. Nohrborgin postillaa eli Autuuden järjestystä luettiin erityisesti Tromssassa (Paulaharju 1928: 461, 479). Lutherin Huone-postillaa, joka oli ilmestynyt vuosina 1846-48 (Tiililä 1961: 16), luettiin Vesisaaressa vuonna 1927 pidetyissä seuroissa, joihin Paulaharjut osallistuivat (Paulaharjun arkisto, KRA S 113: 1940: 37887). Laestadiuksen postilla ilmestyi suomeksi vuonna 1878. Kirjassaan Ruijan äärimmäisillä saarilla Paulaharju (1935: 131) kertoo, miten Laestadiuksen postillaa luettiin seuroissa. Myös muita lestadiolaisia saarnakokoelmia tunnettiin. Paulaharju (1928: 461) mainitsee esimerkiksi lestadiolaisen saarnaajan Laitisen saarnakirjan kveenien lukemina "uudempina" kirjoina. Kyseessä on jokin Aatu Laitisen (1853-1923) julkaisemista saarnakirjoista, joita on useampia. 
Laitinen toimi pappina $\mathrm{mm}$. Rovaniemellä, mutta hänen toimintansa ulottui myös Norjaan, Alattioon, Hammerfestiin ja Koutokeinoon. (Raittila 1967: 253-256.)

Kveenien lukemiin kirjoihin kuului useita eri saarnakokoelmia. Vaikka postilloita saatettiin lukea hiljaakin, niitä todennäköisimmin luettiin ääneen kveenien yhteisissä kokoontumisissa, joita esimerkiksi alattiolaiset kveenit pitivät jo 1700-luvulla (Nielsen 1990: 274). Wegeliuksen ja Francen suomenkieliset postillat kuuluivat myös Jukkasjärvellä, Utsjoella ja Inarissa saamelaisten kirkollisiin kirjoihin, ja Inarissa luettiin myös Ericus Ericin postillaa (Forsgren 1990: 43-44). Luultavimmin kveenit Alattiossa pitivät samanlaisia kokoontumisia eli kylärukouksia, joihin saamelaiset Anderzénin (1996) ja muonionlaaksolaiset Välitalon (1970) mukaan osallistuivat. Koutokeinon kirkollisesta toiminnasta huolehti Ruotsi vuoteen 1751 asti, ja siellä toimivat papit osasivat myös suomea (Rasmussen 2011: 62). Onkin mahdollista, että alattiolaisten kirkollista toimintaa 1700-luvulla järjestettiin Koutokeinosta käsin. Postillojen lukemisen traditio yhteisissä kokoontumisissa jatkui myöhemmin lestadiolaisessa liikkeessä, kuten Paulaharju (1928: 483; 1935: 130) kuvaa.

Saarnakokoelmien lisäksi kveenit lukivat hartauskirjallisuutta, esimerkiksi Johan Arndtin Paratiisin yrttitarhaa (Paulaharju 1928: 124, 461, 479). Alun perin saksankielinen kirja käännettiin suomeksi jo vuonna 1732. Johan Arndt oli luterilaisen ortodoksian edustaja, mutta myös pietistit Suomessa lukivat hänen kirjojansa. Paratiisin yrttitarhasta otettiin jo 1700-luvulla neljä painosta. (Laasonen 2003: 109-110.) Pietismin aikakaudella Arndtin kirjojen omistajia oli paljon erityisesti Torniossa (Vuolasto 2011: 44).

Paratiisin yrttitarhan lisäksi kveenit lukivat muutakin myös Suomessa suosittua hartauskirjallisuutta. Paulaharju (1928: 461) mainitsee esimerkiksi Petter Toppin alun perin ruotsiksi ilmestyneen kirjan Huutawan Ääni Korwesa, joka suomennettiin vuonna 1833. Kirjan julkaisi Henrik Renqvist, jonka kirjapainossa Viipurissa painettiin paljon uskonnollista kirjallisuutta. Renqvistiltä kustannusoikeudet osti Gustaf Otto Wasenius, ja Toppin kirjasta tulikin tämän kustantamon suosituin teos, josta otettiin uusintapainoksia välillä myös sensuurista välittämättä. (Hakapää 2008: 245-246.) Kirjaa painettiin kaikkiaan 18000 kappaletta (Kuparinen 2012: 63).

Ruijassakin luettu hartauskirja oli myös Thomas Wilcoxin Kallis hunajanpisara (Paulaharju 1928: 461). Se oli alun perin englanninkielinen teos, joka käännettiin suomeksi 1779 ja josta otettiin useita uusintapainoksia jo 1800-luvun alkupuolella (Tiililä 1961: 201-202). Pyssyjokelaiset lukivat myös Armonaikaa (Paulaharju 1928: 124), joka viittaa todennäköisesti tanskalaisen Jonas Rasmuksen kirjaan Lyhy ja arwamatoin armon aika, joka oli ruotsin kielestä käännetty suomeksi ja painettu 1808 Turussa J. C. Frenckellin kirjapainossa.

Postillojen lukemisen lisäksi uskonnollinen hartauskirjallisuus kuului erityisesti pietistisiin lukutraditioihin. Hartauskirjoja luettiin todennäköisesti myös hiljaa. Pietististä lukemista kuvaa esimerkiksi wiklundilaiseen pietistiseen liikkeeseen kuuluneen torniolaisen palvelustytön Briitta Joonaantyttären lukuinto: hän harrasti lu- 
kemista jopa töitä tehdessään, esimerkiksi kehrätessään. Kuvaus Briitan lukemisesta on säilynyt oikeudenkäynnin yhteydessä tehdyissä muistiinpanoissa. (Airas 1931: 230, 234-238.)

Tavallinen kansa Suomessa omisti 1700-luvulla eniten virsikirjoja ja katekismuksia (Laine 2018: 44). Monia suomenkielisiä virsikirjoja ja katekismuksia olikin kulkeutunut kveenien mukana Ruijaan. Paulaharju mainitsee "pitkän virsikirjan", joka tarkoittaa ns. vanhaa virsikirjaa. Nimityksen se sai pitkänomaisesta muodostaan (Laine 2018: 50). Tästä virsikirjasta otettiin jo 1700-luvulla 80 painosta. Virallisessa käytössä virsikirja oli vuoteen 1886 saakka, ja vuosina 1800-1886 vanhasta virsikirjasta otettiin vielä 112 painosta. (Lehikoinen \& Kiuru 2009: 27.) Paulaharju (1928: 123, 125, 461) mainitsee pitkän virsikirjan kuuluneen pyssyjokelaisten kirjoihin, ja se kuului myös vesisaarelaisen Kalle Moilasen kirjakokoelmaan. Vanha virsikirja sisälsi myös kalenterin ja ajantiedon, joka lisäsi sen käyttöarvoa (Paulaharju 1928: 125). Norjan museoiden digitaalisilta sivuilta (Digitaltmuseum) voi löytää kaikkiaan neljä kappaletta vanhaa suomalaista virsikirjaa, mikä myös kertoo siitä, että nimenomaan virsikirja näyttää usein kuuluneen kveenien kirjoihin.

Vanhan virsikirjan virsien lisäksi kveenit lauloivat Siionin virsiä ja Siionin matkalauluja (Paulaharju 1928: 124, 461). Siionin virret -kokoelma on käännös ruotsalaisten herrnhutilaisten kokoelmasta "Sions sånger", jonka Elias Lagus käänsi suomeksi vuonna 1790. Virsikokoelmaa käytettiin monien suomalaisten herätysliikkeiden parissa. (Palo 2016: 16-17.) Myös lestadiolaiset käyttivät Siionin virsiä 1800-luvulla, kunnes he alkoivat julkaista omia laulukokoelmiaan. Paulaharjun (1928: 461) mainitsema Siionin matkalauluja -kokoelma, jonka Kalle Moilanen omisti Vesisaaressa, voisi viitata useampaankin lestadiolaiseen laulukokoelmaan (vrt. Holma 2000: 1). Leonard Typpö, lestadiolainen saarnaaja, toimitti 1900-luvun alussa useita laulukokoelmia (Raittila 1967: 211). Risaisesta Typön laulukokoelmasta Kotimaisia virsiä virvoitukseksi vieraalla maalla Jumalan lapsille (1912) laulettiin Kamöyvärin seuroissa, joita Paulaharju kuvailee kirjassaan Ruijan äärimmäisillä saarilla (Paulaharju 1935: 131).

Virsikirjojen ohella katekismukset olivat myös kansan usein omistamaa ja käyttämää kirjallisuutta. Piispa Gezelius vanhemman vuonna 1666 julkaisemaa katekismusta Yxi paras Lasten tavara käytettiin vuosisatojen ajan (Vikman 1910: 88-89). Varsinkin sen ABC-osio, jonka mallina oli Agricolan ABC-kirja, saavutti suuren suosion: siitä otettiin 123 painosta (Kuparinen 2012: 53). Tämä katekismus oli käytössä myös kveenien parissa (Paulaharju 1928: 459). Muitakin katekismuksia luettiin. Esimerkiksi Kalle Moilanen Vesisaaresta omisti "pitkän katekismuksen", joka oli painettu 1831 (Paulaharju 1928: 461). Kyseessä on Svebiliuksen katekismus, joka sai tämän nimityksen - kuten virsikirjakin - pitkänomaisen muotonsa takia. Olaus Svebilius oli Upsalan arkkipiispa, joka julkaisi Lutherin Vähän katekismuksen selityksen vuonna 1693. Porvoon piispa Daniel Juslenius käänsi sen suomeksi, ja se painettiin 1746. Svebiliuksen katekismus on eräs laajimmalle levinneistä uskonnollisista kirjoista 
Suomessa. (Tiililä 1961: 106-107; Kuparinen 2012: 55-56.) Larsen (2012: 96) mainitsee sen olleen lestadiolaisten käytössä Norjassa aina 1800-luvun loppuun asti.

Kveenit siis lukivat aina 1700-luvulta 1900-luvun alkuvuosikymmenille paljon erilaisia uskonnollisia tekstejä. Kveenien lukemien kirjojen tarkastelu osoittaa, että uskonnolliset kirjat, joita usein luettiin Suomessa ja joista otettiin lukuisia uusintapainoksia, olivat käytössä myös Norjassa. Eniten käytettyjä olivat todennäköisesti virsikirja, katekismus ja Raamattu, mutta kveenit lukivat myös postilloita ja hartauskirjallisuutta. Uskonnollisten teosten lukeminen suomeksi ei näytä aiheuttaneen ainakaan kaikille kveeneille ongelmia. Joukosta löytyi aina niitä, jotka osasivat lukea, ja vaikka ketään "täkstin selittäjää" (Paulaharju 1928: 483) ei ollutkaan läsnä, kveenit lukivat keskenään tuttua uskonnollista kirjallisuutta.

\subsection{Kveenien koulukirjat}

Norjassa kansanopetus alkoi vuonna 1739. Kuten naapurimaassa Ruotsissa, opetusta järjesti kirkko, ja lähtökohtana oli pietismin ajatus siitä, että jokaisen piti oppia lukemaan itse keskeiset uskonnolliset tekstit (Jensen 2005: 17-19). Tarkkaa tietoa ei ole siitä, miten kveenilapsia opetettiin 1700-luvulla, mutta esimerkiksi Alattiossa toimi saamen-, norjan- ja kveeninkielinen opettaja 1700-luvulla (Henninen 1972: 122). 1800-luvulla käytiin kiistaa siitä, tulisiko vähemmistöjä opettaa omalla kielellä vai norjaksi (Niemi 2010: 40-42). Molemmat ryhmät saivat omakielistä kouluopetusta kuitenkin vielä 1800-luvun jälkipuoliskolla siitä huolimatta, että norjalaistamiskausi tällöin oli jo alkanut.

Norjassa toimitettiin myös oppimateriaaleja vähemmistöön kuuluvien koululaisten opetukseen. Dahlin (1957: 196) mukaan kveenivähemmistön opetuksessa käytettiin aluksi Suomessa painettuja kirjoja. Kveenilapset lukivatkin mm. edellä esiteltyä Svebiliuksen katekismusta, ja lisäksi saatettiin lukea Lindblomin katekismusta, joka ilmestyi vuonna 1828. Kuparinen (2012: 56) mainitsee tätä katekismusta käytetyn Suomessa erityisesti kaupunkialueilla.

Opetuksen helpottamiseksi alettiin kuitenkin tuottaa oppikirjoja, joissa oli rinnakkain kveenin- ja norjankielinen teksti. Samat tekstit olivat olemassa myös saamen- ja norjankielisinä. Näin opetus usein monikielisissä luokkahuoneissa helpottui. Vuonna 1864 kveenilasten opetusta varten painettiin kaksikielinen Vogtin Raamatunhistoria, joka painettiin uudestaan vuonna 1884 (Sainio 1949: 20). J. A. Friis julkaisi vuonna 1864 ABC-kirjan, jossa kveenin- ja norjankielinen teksti olivat rinnakkain. ABC-kirja julkaistiin uudestaan vuonna 1867. (Sainio 1949: 9; Dahl 1957: 197-198, 245-246.) Vuonna 1879 painettiin Lyhyt ote Dr. Erik Pontoppidanin Selityksestä (Sainio 1949: 15). Kyseessä oli H. U. Sverdrupin toimittama Erik Pontoppidanin jo 1700-luvulla laatima Lutherin Vähän katekismuksen selitys, jota käytetiin Norjan kouluissa oppikirjana melkein 150 vuotta (Flottorp 2019). 
Myös koulukirjat olivat siis sisällöltään pääasiassa uskonnollisia. Vaikka kaksikielisten koulukirjojen päämääränä olikin opettaa kveenilapsille norjaa (Dahl 1956: 210-211), tuloksena saattoi kuitenkin olla myös lukutaito omalla kielellä. Paulaharju (1928: 524-525) kuvaa kveenilasten oppineen lukemaan omalla kielellään niin kauan kuin kaksikieliset kirjat vielä olivat käytössä, ja jotkut opettajistakin osasivat suomea.

\subsection{Maallinen kirjallisuus}

Varhaisnykysuomen kaudella vuosina 1820-1870 suomen kielen kirjallinen käyttö laajeni käsittämään myös maallisen kirjallisuuden. Kirjallisuuden lajivalikoima kasvoi erityisesti 1800-luvun loppupuolella. (Leino-Kaukiainen 1989: 339; Pulkkinen 1972: 83-84.) Juuri tänä samana ajankohtana Norja sai runsaasti lisää kveeniasukkaita. Esittelen tässä luvussa kveenien kosketusta kehittyvään suomen kirjakieleen ja erityisesti suomeksi kirjoitettuun maalliseen kirjallisuuteen.

Fennomaanien tavoitteena oli Suomen kielen aseman parantaminen paitsi Suomen suurruhtinaskunnassa, myös autonomisen Suomen rajojen ulkopuolella. Erityisesti pantiin merkille suomalaisperäisen vähemmistön kieliolot Ruotsissa ja Norjassa. Suomalaisen kirjallisuuden seura lähettikin stipendiaatti David Skogmanin tutustumaan vuonna 1865 näihin vähemmistöihin. Tavoitteena oli kerätä kansanperinnettä, ja sen lisäksi tutustua vähemmistöjen kielioloihin. Esimerkiksi kveenien kielitilannetta pyrittiin parantamaan hankkimalla heille suomenkielistä kirjallisuutta. (Ryymin 2004: 99-107.)

Skogmanin aloitteesta Suomessa järjestettiin talkoot, joiden avulla kveeneille toimitettiin suuri määrä kirjoja. Ryymin (2004: 99-112) on kartoittanut Skogmanin toimintaa Norjassa. Kirjoja hankittiin lehtikirjoittelun perusteella: jotkut lehdet julkaisivat David Skogmanin kirjoituksen kirjojen tarpeellisuudesta, ja lukijat osallistuivat talkoisiin lähettämällä kirjallisuutta, joka toimitettiin Norjaan. Sanomalehdissä myös yleensä kerrottiin lukijoille, millaista kirjallisuutta talkoiden avulla Norjaan oli lähetetty. Kirjoja lähetettiin esimerkiksi Tromssaan ja Alattioon, muun muassa Kaavuonon kaivoksessa työskenteleville kveeneille.

Helsingfors Tidningar oli eräs Norjaan kirjoja toimittanut sanomalehti (Ryymin 2004: 104, alaviite 127). Vuonna 1865 lehdessä kirjoitettiin, että Norjaan oli lähetetty kaikki J. H. Lilljan kirjapainossa painetut kirjat, yhteensä 655 nidettä (Helsingfors Tidningar 19.7.1865). Myös P. Th. Stolpe lähetti 38 suomeksi kustantamaansa kirjaa Norjaan (Helsingfors Tidningar 20.7.1865; Suometar 21.7.1865). Stolpe piti kirjakauppaa ja lainakirjastoa Helsingissä (Hakapää 2008: 351), mutta tämän lehtitiedon mukaan hänellä näyttäisi olleen myös kustannustoimintaa. Monet muutkin henkilöt osallistuivat talkoisiin, ja lahjoittivat pienempiä kirjalahjoituksia Norjaan (Helsingfors Tidningar 31.8.1865). 
Vuonna 1880 Vesisaareen puuhattiin myös kirjastoa, josta maksua vastaan saattoi lainata lukemista suomeksi (Ryymin 2004: 170). Osa näistä kirjoista oli vielä jäljellä Paulaharjujen käydessä Vesisaaressa (1928: 463-465). Paulaharju mainitsee vanhaan lainakirjastoon kuuluneen uskonnollisten kirjojen lisäksi esimerkiksi Topeliuksen, Eurénin ja Snellmanin kirjoja, Juhani Ahon Siihen aikaan kun isä lampun osti, joka ilmestyi ensimmäisen kerran 1883, ja näiden lisäksi Suomen historiaa käsitteleviä kirjoja. G. E. Eurén kirjoitti ja käänsi monet edellä mainitun kirjakustantaja Lilljan julkaisemasta Lukemisia kansalle -sarjan kirjoista (Autero 1993: 106). Kirjastoon kuului myös A. V. Ervastin kirja Suomalaisia Jäämeren rannalla, joka ilmestyi 1884. Ervasti oli oululainen lehtimies, jonka matkakertomus kuvaa sekä Norjassa että Venäjällä asuvia suomalaisia. Kirja sai aikaan laajaa keskustelua suomalaisessa lehdistössä, ja se herätti huomiota myös Norjassa, koska siinä kritisoitiin Norjaa kveenien huonosta kohtelusta. Kirjassa esiintyneet ajatukset siitä, että kveenit mielellään liittyisivät Suomeen, säikähdyttivät norjalaisia ja vaikeuttivat Suomen ja Norjan suhteita. (Varpio 1997: 92-98.)

Paulaharju (1928: 464) mainitsee erään vesisaarelaisen lukeneen Niemelän talon joulunvietosta. Kyse on mahdollisesti Johannes Häyhän kirjoittamasta kirjasta Kuvaelmia Itä-Suomalaisten vanhoista tavoista 1 - Joulun vietto, jossa kerrotaan joulun vietosta Niemelän talossa. Tämä kuvaus ilmestyi alun perin Kansanvalistusseuran julkaisemana vuonna 1893. (Vallinkoski \& Schauman 1986, nro 5141.) Paulaharju mainitsee myös Päivärinnan Kuoppa-Tanelin kirjan (1928: 464), jota luettiin Näätämössä (Paulaharjun arkisto, KRA S 113: 1940: 38034). Pietari Päivärinta oli suosittu ja tuottelias 1800-luvun kansankuvaaja, joka kuvasi köyhän kansan kuten torppareiden elämää (Huhtala 1981: 55-61). Kuoppa-Tanelin kirjaa ei kuitenkaan löydy Päivärinnan kirjoitusten joukosta esimerkiksi Suomen kirjailijat -teoksesta (Hirvonen 1993).

Vesisaarelaisen Kalle Moilasen kirjoihin (Paulaharju 1928: 462) kuului Johannes Rännärin kirja Palestina eli Kanaan maa, joka oli painettu Oulussa 1863 (Hirvonen 1993: 656). Pyssyjoessa luettiin Turussa 1861 painettua Sven Samuelinpojan Hevoiskirjaa (Paulaharju 1928: 461), joka mainitaan S. G. Elmgrenin Suomen kirjallisuusluettelossa (Elmgren 1865: 153).

Myös Kalevala esiintyy Paulaharjulla (1935: 95-96) esimerkkinä siitä, että muutakin kuin uskonnollista kirjallisuutta luettiin Ruijassa. Kalevalaa säilytettiin Ryssämarkan kirkon kaapissa, ja pappi lainasi sen lukemiseksi kirkon rantaan tuulen tyyntymistä useaksi päiväksi odottamaan jääneille kveeneille. Vielä vanhana Kalevalan lukemista kuunnellut Krikan Sammu tiesi kertoa Paulaharjulle, mitä Väinämöisen raamatussa kerrottiin.

Kveenien joukossa oli myös henkilöitä, jotka omistivat enemmän kirjallisuutta kuin oli tavallista. Esimerkiksi Reisivaarassa kauppias Tuomas Gunnarilla oli paljon kirjoja, ja hänen poikansa kirjakaapissa oli Koru-Kalevala, Seitsemän veljestä, Oma maa, Tietosanakirja ja muitakin suomalaisia kirjoja norjankielisten kirjojen lisäksi 
(Paulaharju 1928: 204-205). Kuitenkaan monella ei ollut varaa näin laajan kirjaston hankkimiseen.

Maalliseen kirjallisuuteen kuuluivat myös arkkiveisut, jotka Suomessa edustivat maallisen kirjallisuuden lajia jo 1700-luvulla. Arkkiveisut olivat suosittua lukemista, koska ne olivat halpoja ja niiden saanti oli helppoa. Arkkiveisuja myytiin esimerkiksi markkinoilla. (Hakapää 2008: 240-241.) Kveenien kiinnostusta arkkiveisuja kohtaan osoittaa esimerkiksi se, että niitä sekä tuotiin Suomesta että joskus painettiin myös Tromssassa (Paulaharju 1928: 462; Sainio 1949).

Kun suomenkielinen sanomalehdistö alkoi kehittyä ja levikki laajentua 1800-luvun loppupuoliskolla (Tommila \& Salokangas 2000: 54), alettiin myös Ruijaan tilata suomenkielisiä sanomalehtiä. Vesisaaressa luettiin erityisesti Oulussa ilmestynyttä Kaikua, mutta myös joitakin muita sanomalehtiä. Vesisaareen yritettiin myös perustaa omaa suomenkielistä sanomalehteä, mutta yritys kariutui tilaajien puutteeseen. (Paulaharju 1928: 466-478; Ryymin 2004: 132-135.)

Eräs pykeijalainen kertoi Paulaharjulle 1928, miten hänen äitinsä oli lukenut ääneen sanomalehtiä naapurin miehille. Eräs miehistä toi luettavaksi myös almanakan ja lorukirjoja, joita hän oli hankkinut Suomessa käydessään. Ääneen saatettiin lukea siis muutakin kuin uskonnollista kirjallisuutta. (Paulaharjun arkisto, KRA S 113: 1940: 37917.)

Ainakin joitakin varhaisnykysuomen ja jopa nykysuomen kauden suomenkielisestä maallisesta kirjallisuudesta siis päätyi myös Ruijaan asti. Seuraavassa luvussa pohdin, miksi maallisen kirjallisuuden lukeminen omalla kielellä ei kuitenkaan saavuttanut laajaa lukijakuntaa kveenien parissa.

\section{Lukemisen kulttuurit ja kveenit}

Kveenien lukeminen liittyi uskonnon harjoittamiseen. Suomenkielisen kirjallisuuden lukemistraditio perustui luultavasti vanhaan, jo 1700-luvulta peräisin olevaan kylärukoustraditioon, jossa kokoonnuttiin koteihin lukemaan uskonnollisia tekstejä kirkossa käymisen sijasta (Anderzen 1996: 7-14; Välitalo 1970: 20-35). Kiinnostus lukemiseen kuului myös pietismiin, joka levisi Pohjois-Suomeen 1700-luvun loppupuolella. Pietismin vaikutus näkyy kveenien keskuudessa esimerkiksi pietismin kauden postillojen ja hartauskirjallisuuden lukemisena. Lukemisen kulttuurin kannalta pietistien lukeminen on tulkittu välittäjäksi aikaisemman luterilaisen puhdasoppisuuden kauden pakkolukemisen ja omaehtoisen, haluun perustuvan lukemisen välillä. Pietistien lukemista Mäkinen (1997: 37-38) kutsuu intensiiviseksi toistolukemiseksi. Pietistiselle liikkeelle oli jatkoa lestadiolaisuus, joka sai vahvan jalansijan niin pohjoisilla alueilla Suomessa ja Ruotsissa kuin myös kveenien ja saamelaisten keskuudessa Norjassa (Larsen 2012: 14-15). Myös lestadiolaisuudessa uskonnollisen kirjallisuuden lukemisella oli tärkeä asema. 
Paulaharju (1928: 124) esittää useita kuvauksia kveenien lukemistraditiosta. Raamatun tekstejä ja hartauskirjallisuutta kokoonnuttiin lukemaan vuoron perään eri taloihin. Samoja tekstejä luettiin uudelleen ja uudelleen. Paulaharju kertoo, kuinka "ikivanhat pyhät kotoisat kirjat" olivat käytössä kuluneet:

"Ja vanhat kirjat, ruskeiksi, risaniskoiksi tutkiskellut armon välikappaleet, joiden joka aukeamalla on mustunut peukalonpainuma, täysin soveltuvatkin kyläkansan puheenparteen. Ne julistavat oikeaa jumalansanaa, jota yksinkertainen takarannan kansakin ymmärtää. Mutta uusissa Suomen kirjoissa on kovin outoa kieltä." (Paulaharju 1928: 124-125.)

Vanhalla kirjasuomella kirjoitettu uskonnollinen kirjallisuus oli kveeneille tuttua, koska sitä oli luettu jo 1700-luvulta lähtien. Vaikka samoja kirjoja luettiinkin yhä uudestaan, uskonnollista kirjallisuutta hankittiin myös jatkuvasti lisää. Kirjat kulkivat mukana, kun muutettiin Norjaan, tai niitä toimittivat henkilöt, jotka kuljettivat tavaraa Suomen ja Norjan välillä. Myös Norjaan jutaavat saamelaiset kuljettivat kirjoja mukanaan Suomesta tullessaan. (Paulaharju 1928: 460-462.)

Ekstensiivinen lukeminen, jossa luetaan paljon tekstejä, edellyttää paitsi luettavia tekstejä myös niiden helppoa saatavuutta. Ekstensiivinen lukeminen lisääntyi Suomen kansan keskuudessa tekstien määrän kasvaessa. Tämä tapahtui varhaisnykysuomen aikana, jolloin suomenkielisen kirjallisuuden määrä kasvoi (Leino-Kaukiainen 1989: 389-390). Tosin Laine (2017: 165) esittää, että ekstensiivinen lukeminen kansan keskuudessa oli mahdollista jo 1700-luvullakin, koska jo silloin painettiin uskonnollisen kirjallisuuden lisäksi muitakin tekstejä, kuten asetuksia, kuulutuksia, arkkiveisuja jne. Mäkinen (1997: 416) kuitenkin toteaa, että suomenkielinen väestö Suomessa alkoi lukea modernissa mielessä vasta 1800-luvun lopulla. Kyse on paitsi lukutaidosta ja luettavien tekstien määrästä, myös siitä, miten helposti luettavaa saattoi hankkia. Siinä esimerkiksi kirjastolaitoksella oli tärkeä merkitys.

Joillakin kveeneillä oli käytössään suomeksi kirjoitettuja tekstejä varhaisnykysuomen kaudelta ja myös nykysuomalaisen kauden tekstejä. Joitakin poikkeuksia lukuun ottamatta näyttää kuitenkin siltä, että suurin osa kveeneistä ei koskaan siirtynyt moderniin ekstensiiviseen lukemiseen omalla kielellään, vaan tämä tapahtui norjaksi. Syitä tähän lienee useita. Vaikka maallista kirjallisuutta suomeksi toimitettiin kveenien pariin, tämä kirjallisuus ei ehkä tavoittanut kaikkia lukuhaluisia. Toisaalta lukeminen haluttiinkin rajoittaa vain uskonnollisiin kirjoihin, koska maallisten kirjojen lukemista pidettiin ajanhukkana, ainakin jos niitä luettiin vain huvin vuoksi. (Paulaharju 1928: 462).

Suomen kielen uudistaminen aiheutti lisäksi sen, että uudella kielimuodolla kirjoitettuja tekstejä oli vaikea lukea. Uuden suomen kielimuodon vierastaminen tuleekin esille Paulaharjun kirjoissa (1928: 125, 522). Kun vanhoihin kirjoihin palattiin aina uudestaan, oudoksi koetulla kielellä kirjoitetut kirjat jäivät lukematta. Esimerkiksi kveenien lainakirjastoon 1800-luvun loppupuolella saapuneet kirjat löytyivät 
"tomuttuneena kasana" ullakolta Paulaharjujen käydessä Vesisaaressa. Niitä ei kukaan enää kaivannut. (Paulaharjun arkisto, KRA S 113: 1940: 38033.)

Keskeinen syy omakielisen lukemiskulttuurin ohentumiseen oli se, että omakielisen lukemisen funktio kveenien keskuudessa oli lähinnä uskonnollinen. Kun uskonnon ote enää ei ollut niin vahva, omakielisen lukemisen merkitys väheni. Tätä kehitystä Paulaharju kuvaa jo Ruijan äärimmäisillä saarilla -kirjan luvussa, joka kertoo Kamöyvärin seuroista. Nuoriso ei niihin enää osallistunut, vaan käytti sunnuntaipäivänsä muuhun kuin seuroissa istumiseen ja suomenkielisen postillan lukemisen kuuntelemiseen:

"Sillä nuori kansa on maailmanmielistä. Heistä on paljon mieluisampaa kirkkaana pyhäpäivänä korein vaattein astua kapsutella ilakoiden pitkin kylätietä ja katsella toistensa sieviä muotoja kuin katsella saarnatuvassa kurttuisia naamoja; heistä on paljon hauskempaa soudella merellä ja pelehtiä Kamöijan ruohoisella rannalla kuin istua tunkkaisessa tuvassa veisata killittämässä ja kuuntelemassa unettavaa saarnaa, josta ei tahdo tulla loppuakaan. Kun Penjami yhä vain kääntää ja kääntää lehteä ja yhä lukea paukuttaa, ja Nilsan Petteri sitten vielä tolkkaa sitä ruijaksi, niin kuka sellaista jaksaa kuulla - kun on nuori ja iloinen, ja kirkas joutopäivä... Istukoot vanhat ja kuunnelkoot, heillä ei ole muuta hupia!" (Paulaharju 1935: 130.)

Kveenit muuttuivat myös yhä enemmän kaksikielisiksi. Norjan lukeminen ja kirjoittaminen ei tuottanut enää vaikeuksia. Kun kosketus suomen kirjakieleen heikkeni, ja tekstejä oli helpommin saatavilla norjaksi, omakieliset kirjalliset taidot rapistuivat ja katosivat. Kouluissa oli omakielistä alkeisopetusta annettu kveenilapsille vielä 1800-luvun loppupuolella. Kouluissa norjalaistamiseen pyrkivä lainsäädäntö kuitenkin vahvistui 1800-luvun lopulla, ja mahdollisuus käyttää kveeniä apukielenä kouluissa poistettiin koululaista vuonna 1936 (Niemi 2010: 41-44). Viranomaisten arvio oli, että kveenit osasivat jo niin paljon norjaa, että tätä mahdollisuutta ei enää tarvittu. Monet kveenitkin hyväksyivät ajatuksen, että Norjassa oli tärkeä ennen kaikkea osata maan kieltä. Esimerkiksi Vesisaareen yritettiin perustaa omaa koulua kveenilapsille, mutta koulu ei koskaan saanut suurta suosiota, ja se jouduttiin lakkauttamaan (Paulaharju 1928: 525-526).

Monet kveenit ja kveeniyhteisöt kokivatkin kielenvaihdon 1900-luvun kuluessa. Yhteiskunnan modernisoituminen oli tämän kehityksen eräs perusta. Lukutaito ei enää kuulunut pelkästään uskonnolliseen kontekstiin, vaan yhteiskunta edellytti lukutaitoa esimerkiksi monissa ammateissa. Koululaitos laajeni ja tehostui, ja Pohjois-Norjassa koulutuksen tehoa pyrittiin lisäämään esimerkiksi kouluinternaattien avulla. Niissä kveenien norjalaistaminen saatiin lopullisesti toteutettua. Myös syrjäkylien lapset, joista jotkut vielä 1950-luvullakin osasivat vain kveeniä, joutuivat internaateissa täysin norjalaiseen ympäristöön, ja monet vaihtoivat kielensä (Lindgren 2009: 112-115). 
Suomenkielistä kirjallisuutta ei ollut juuri saatavilla julkisissa kirjastoissa. Vesisaaressa toimiva Finmarkun kirjasto julkaisi 1925 kirja- ja sanomalehtiluettelon (Balke 1925), johon sisältyy vain sivun verran kirjallisuutta kveeneille, enimmäkseen edellä esiteltyjä oppikirjoja ja uskonnollista kirjallisuutta. Kveenejä ei toisin sanoen kannustettu lukemaan äidinkielellään. Sen sijaan Finmarkun kirjasto sai 60000 kruunun kirjalahjoituksen norjankielisten kirjojen hankkimista varten 1930-luvulla. Lahjoituksen päämääränä oli norjan kielen vahvistaminen alueella. Kveenikoteihin toimitettiin lisäksi ilmaisia norjankielisiä lehtiä. (Eriksen \& Niemi 1981: 241-243.)

Myös Ruotsin puoleisessa Tornionlaaksossa kehitys eteni niin, että suomenkielinen väestö, joka oli osannut lukea omaa kieltään vielä 1900-luvun alkupuolella, siirtyi ruotsinkielisen kouluopetuksen johdosta käyttämään lähinnä vain ruotsia kirjallisena kielenään. Ruotsin kielen käytön lisääntyminen liittyi sielläkin tietoisen ruotsalaistamispolitiikan lisäksi yhteiskunnan modernisoitumisprosessiin.

Kansakoulu oli suomenkielinen vielä 1800-luvun lopulla, ja lukemisen opetuksen lisäksi Tornionlaaksossa opittiin myös kirjoittamaan suomea. Kosketus kehittyvään suomen kirjakieleen jäi kuitenkin vähäiseksi, ja omaa kieltä käytettiin lähinnä kotona ja uskonnollisissa yhteyksissä. (Elenius 2001: 324-325, 414-415.)

\section{Uskonnollinen lukeminen ja kielen säilyminen}

Kveeniväestöä alkoi siirtyä enenevässä määrin Norjaan jo yli kolme sataa vuotta sitten, ja edelleen jotkut kveenit puhuvat kieltään. Millainen merkitys uskonnollisella, intensiivisen lukemisen kulttuurilla on ollut kielen säilymisen kannalta? Grenoble \& Whaley (2006: 109) korostavat, että kirjalliset taidot ovat kieltä säilyttäviä silloin, kun niillä on kielenpuhujien kannalta tärkeä funktio puhujan omassa yhteisössä. Kveenien lukemisen kulttuuri liittyi omakieliseen uskonnon harjoittamiseen. Kun luku- ja kirjoitustaitoa ei nähdä pelkästään teknisenä taitona, vaan se on osa yhteisön harjoittamia kielellisiä käytänteitä eli toistuvaa kielellistä toimintaa (Pennycook 2017: 139), sillä on merkitystä kielen säilymiselle. Vaikka uskonnollinen kielenkäyttö voikin poiketa arkipäivän kielestä - kuten vanha kirjasuomi poikkeaa kveenimurteista - auttaa säännöllinen tekstien lukeminen ja kuunteleminen säilyttämään kieltä (Pauwels 2016: 137-138). Ääneen lukemisen traditio vaikutti lisäksi siten, että myös lukutaidottomat pääsivät osallistumaan kirjakielen käyttämiseen (vrt. Laine 2017: 9-11).

Lestadiolaisuutta ei ole pidetty pelkästään uskonnollisena, vaan myös sosiaalisena liikkeenä, joka on yhdistänyt kveenejä kulttuurisesti (Larsen 2012: 306-308) ja joka lisäksi on vaikuttanut vähemmistökielen säilymiseen (Lindgren 2009: 113-114). Lestadiolaisissa seuroissa myös kääntäminen kielestä toiseen on kuulunut normaaleihin käytänteisiin, mistä esimerkkinä on jo edellä esitetty katkelma Kamöyvärin seuroista. Tällä tavalla myös vähemmistökielet ovat olleet liikkeessä esillä. Lisäksi les- 
tadiolaisuus on ollut kansallisia rajoja ylittävä liike, ja seurapuhujia Norjaan on usein hankittu Suomesta. Näin säilyi myös kosketus suomalaiseen kieliyhteisöön (Ryymin 2004: 296).

Uskonnon harjoitus on vaikuttanut myös muissa vähemmistöyhteisöissä kieltä säilyttävästi. Lestadiolaisuudella on ollut merkitystä myös meänkielen säilymiselle ruotsinpuoleisessa Tornionlaaksossa muiden tekijöiden ohella (Elenius 2001: 416). Paunonen (2018: 17) tuo esille, että suomen kirjakieltä Ruotsin Tornionlaaksossa käytettiin erityisesti lestadiolaisten parissa. Hän jopa arvelee uskonnollisen kielenkäytön vaikuttaneen joihinkin meänkielessä esiintyviin kielen piirteisiin (Paunonen 2018: 148).

Luterilainen uskonto on vaikuttanut inkerinsuomen säilymiseen ortodoksiseen kirkkokuntaan kuuluvien venäjänkielisten keskuudessa. Sen sijaan inkerikot ja vatjalaiset ovat sulautuneet helpommin venäläisiin, koska he kuuluvat samaan uskontokuntaan. (Nevalainen 1991: 162-164.) Uskonnon harjoittamisen merkitys kielen säilyttämisen kannalta ei toisin sanoen ole yksiselitteistä. Lestadiolaisethan kuuluvat samaan luterilaiseen kirkkokuntaan kuin enemmistöön kuuluvat sekä Norjassa että Ruotsissa, mutta siitä huolimatta liikkeen on nähty vaikuttaneen vähemmistökielen säilymiseen.

Yhteiskunnalliset muutokset ja sekularisoituminen johtivat kuitenkin siihen, että lestadiolaisuus leimautui vanhoilliseksi ja epämoderniksi, ja monet nuoret käänsivät liikkeelle selkänsä (Aadnanes 1986: 100-101; Elenius 2001: 416). Vaikka kveeni on sälynyt puhuttuna kielenä, kosketus kirjoitettuun suomen kieleen katkesi, kun uskonnollisen kirjallisuuden lukemisen traditio katosi.

Nykyinen kveenin elvytys perustuu puhutun kveenin kirjallistamiseen. Tämä johtuu siitä, että monet kveenit kokevat suomen kirjakielen heille vieraaksi kielimuodoksi (Lindgren 2009: 108). Osa kveeneistä kuitenkin kannattaa sitä, että suomen kirjakieli voisi toimia myös kveenien kirjallisen ilmaisun kielenä (Udir 2015). Myös tällaisen näkemyksen voi helpommin ymmärtää, kun tuntee suomen kirjakielen käytön pitkän, joskin kesken katkenneen tradition kveenien keskuudessa.

\section{Loppusanat}

Kveeneillä on ollut pitkä, aina 1700-luvulta peräisin oleva suomenkielisen kirjallisuuden lukemistraditio. Kveenit lukivat kirjoja, jotka olivat päässeet suuriin painoslukuihin myös entisessä kotimaassa ja kuuluivat siellä tavallisen kansan lukemiin kirjoihin. Katekismus, virsikirja ja Raamattu kuuluivat perusteoksiin, mutta muutkin uskonnolliset teokset, jotka saavuttivat suuren suosion Suomessa, päätyivät myös kveenien lukemistoksi Norjaan. 
Omakielinen lukemisen traditio todennäköisesti auttoi kveenejä säilyttämään kieltään läpi vuosisatojen, koska sillä oli tärkeä funktio kveeniyhteisöissä. Lukeminen kuului kveenien omakielisiin kulttuurisiin käytänteisiin, ja omakielisten tekstien lukemista harjoitettiin säännöllisesti uskonnollisissa kokoontumisissa eri aikakausina. Kun siirryttiin uskonnollisesta toistolukemisesta ekstensiiviseen lukemiseen modernina aikana, omakielisen lukemisen traditio katkesi. Monet kokivat myös uudistetun suomen kirjakielen itselleen vieraaksi. Vaikka kveeni on säilynytkin puhuttuna kielenä, norjasta on tullut usein kveenien ainoa kirjallisen sivistyksen kieli.

Kveenin kielen elvytyksen yhteydessä on tärkeä miettiä sitä, millaisia kirjallisia ja suullisia funktioita ja käytänteitä elvytettävällä kielellä on kielenkäyttäjien keskuudessa, ja voidaanko niitä tietoisesti kehittää. Kielenelvytyksen edellytyksenä on, että kieli myös otetaan käyttöön. Kulttuurin ja yhteiskunnan muuttuessa kielelliset käytänteet ja kielenkäytön domeenit luonnollisesti muuttuvat. Ennen veisattiin virsiä seuratuvassa, nykyisin kveeniä voidaan käyttää vaikkapa räppäämiseen YouTubessa.

\section{Lähteet}

\section{Tutkimusaineisto}

Paulaharjun arkisto. SKS. Keräelmä. (Teksti) KRA S 113: 1940: [37879-38044].

Digitaltmuseum

https://digitaltmuseum.no

Henrik-tietokanta. Kirjojen omistus Suomessa vuoteen 1809. SKS.

http://dbgw.finlit.fi/henrik/henrik_tietokanta.htm

Historiallinen sanomalehtikirjasto

https://digi.kansalliskirjasto.fi/sanomalehti/search

\section{Kirjallisuus}

Aadnanes, P. M. 1986. Læstadianismen i Nord-Norge. Kolbotn: TANO.

Airas, K. 1931. Kirkollista elämää ja hengellisiä liikkeitä Tornionjokilaakson alaosilla 1675-1809. Suomen kirkkohistoriallisen seuran toimituksia XXIX. Helsinki: Helsingin uusi kirjapaino.

Anderzen, S. 1996. 'The Ways of the Textword' in Church Tradition: Christian Mission Schooling among the Saami in Torne and Kemi Laplands in the 1700s. Acta Borealia, $13(2), 3-22$.

Autero, O. 1993. J. W. Lillja 1817-1878. Historiallisia tutkimuksia 172. Helsinki: Suomen historiallinen seura.

Balke, G. 1925. Katalog over Finmarksbibliotekets bok- og avissamling. Vadsø: Vads ø Trykkeri. Berg-Nordlie, M. 2018. Finner - samer. Teoksessa Store norske leksikon. https://snl.no/ finner_-_samer. [Luettu 11.6. 2019.]

Dahl, H. 1957. Skråkpolitikk og skolestell i Finnmark 1814-1905. Oslo: Universitetsforlaget. 
Elenius, L. 2001. Både finsk og svensk. Modernisering, nationalism och språkförändring i Tornedalen 1850-1939. Umeå: Kulturgräns norr.

Elmgren, S. G. 1865. Öfversigt af Finlands litteratur: Ifrån år 1771 till 1863. Helsinki: K. Alexanders universitet.

Eriksen, K. E. \& E. Niemi 1981. Den finske fare. Sikkerhetsproblemer og minoritetspolitikk i nord 1860-1940. Oslo: Universitetsforlaget.

Fellman, J. 1978. Anteckningar under min vistelse i Lappmarken. Hangö: Raben \& Sjögren.

Flottorp, H. 2019. Erik Pontoppidan - teolog. Teoksessa Store norske leksikon. https://snl.no/ Erik_Pontoppidan_-_teolog. [Luettu 11. 6. 2019.]

Forsgren, A. \& A. Minken 2019. Kvener. Teoksessa Store norske leksikon. https://snl.no/kvener. [Luettu 11.6.2019.]

Forsgren, T. 1990. «...först at inhänta språket, och sedan deruppå lära sin Christendom...» Om finska böcker och sameundervisning i Torne og Kemi lappmarker före 1850. Scriptum nr. 26. Umeå: Forskningsarkivet vid Umeå Universitet.

Grenoble, L. A. \& L. J. Whaley 2006. Saving languages. An introduction to language revitalization. Cambridge: Cambridge University Press.

Hakapää, J. 2008. Kirjan tie lukijalle: kirjakauppojen vakiintuminen Suomessa 1740-1860. Helsinki: Suomalaisen Kirjallisuuden Seura.

Hammond, H. 1787. Den Nordiske Missons-Historie i Nordlandene, Finnmarken og Trundhiems Amt. Kiøbenhavn.

Heininen S., T. Laine, J. Knuutila \& E. M. Laine 1997. Teologia. Teoksessa T. Laine (toim.) Vanhimman suomalaisen kirjallisuuden käsikirja. Helsinki: Suomalaisen Kirjallisuuden Seura, 49-179.

Henninen, T. 1972. Den kvenske innvandring til Alta på 1700-tallet. Hovedoppgave i historie. Universitetet i Trondheim.

Hirvonen, M. (toim.) 1993. Suomen kirjailijat 1809-1916. Suomalaisen Kirjallisuuden Seuran Toimituksia 570. Helsinki: Suomalaisen Kirjallisuuden Seura.

Hiss, F. 2017. Workplace multilingualism in shifting contexts: A historical case. Language in Society, 46 (5), 697-718.

Holma, T. 2000. Lestadiolaisen lauluperinteen historiaa. http://www.tornio.fi/kirjasto/torkok/ laestadius/tholma2.htm.

Huhtala, L. 1981. Kuu torpparin aurinko. Torppari-aihe suomalaisessa kaunokirjallisuudessa 1809-1918. Helsinki: Suomalaisen Kirjallisuuden Seura.

Häkkinen, K. 1994. Agricolasta nykykieleen. Suomen kirjakielen historia. Juva: WSOY.

Jensen, E. B. 2005. Skoleverket og de tre stammers møte. Tromsø: Eureka.

Kuparinen, R. 2012. Seitsemän veljeksen rippikoulu. Pro gradu -tutkielma. Helsingin yliopisto. https://helda.helsinki.fi/handle/10138/36530.

Laasonen, P. 2000. Finlands kyrkohistoria II. Åren 1593-1808. Översettning från finskan: Bill Widén. Malmø: Artos bokförlag.

Laasonen, P. 2003. Katsaus saksalaisperäiseen kirjallisuuteen Suomessa 1600- ja 1700-luvuilla. Teoksessa T. Laine (toim.) Vieraskielinen kirjallisuus Suomessa Ruotsin vallan aikana. Helsinki: Suomalaisen Kirjallisuuden Seura, 104-113.

Laine, T. 2017. Aapisen ja katekismuksen tavaamisesta itsenäiseen lukemiseen. Rahvaan lukukulttuurin kehitys varhaismodernina aikana. Helsinki: Suomalaisen Kirjallisuuden Seura.

Laine, T. 2018. Kirjahistorian perusteet ja tutkimus. Helsinki: Kansalliskirjasto ja Suomen kirjahistoriallinen seura ry. https://doi.org/http://urn.fi/URN:ISBN:978-951-51-4040-1.

Larsen, R. I. 2012. Religion og fiendebilder. Læstadianismen, statskirken og kvenene 1870-1940. Tromsø: Universitetet i Tromsø. 
Lehikoinen, L. \& S. Kiuru 2009. Kirjasuomen kehitys. Uudistettu laitos, 7. painos. Helsinki: Helsingin yliopiston suomen kielen laitos.

Leino-Kaukiainen, P. 1989. Suomen kielen käytön yleistyminen. Teoksessa P. Tommila \& M. Pohls (toim.) Herää Suomi: suomalaisuusliikkeen historia. Jyväskylä: Kustannuskiila Oy, 329-346.

Lindgren, A.-R. 2009. Kvensk i Norge. Teoksessa T. Bull \& A.-R. Lindgren (toim.) De mange språk i Norge. Flerspråklighet på norsk. Oslo: Novus forlag, 107-124.

Maliniemi, K. 2010. Hva arkivene skjulte. En undersøkelse av kvensk og samisk i offentlige arkiver i Kistrand Porsanger og Nordreisa 1865-1948. Oslo: ABM-Media AS.

Mäkinen, I. 1997. Nödvändighet af LainaKirjasto. Modernin lukuhalun tulo Suomeen ja lukemisen instituutiot. Helsinki: Suomalaisen Kirjallisuuden Seura.

Nevalainen, P. 1991. Silmäys Inkerin kirkollisiin oloihin 1704-1917. Teoksessa P. Nevalainen \& H. Sihvo (toim.) Inkeri. Historia, kansa, kulttuuri. Suomalaisen Kirjallisuuden Seuran toimituksia 547. Pieksämäki: Suomalaisen Kirjallisuuden Seura, 159-166.

Nielsen, J. P. 1990. De glemte århundrene 1520-1826. Alta: Alta kommune.

Niemi, E. 1977. Opprudd og tilpassing: den finske flyttingen til Vadsø 1845-1885. Vadsø: Vadsø kommune.

Niemi, E. 2010. Kvenene - Nord-Norges finner. En historisk oversikt. Teoksessa B. B. Moen \& A. C. B. Lund (toim.) Nasjonale minoriteter i det flerkulturelle Norge Trondheim: Tapir akademisk forlag, 32-52.

Palo, M. 2016. Kirjoja lukevat körtit - Ylistaron Untamalan kylän uskonnollinen kirjallisuus vuoteen 1920. Pro gradu -tutkielma. Helsingin yliopisto. https://helda.helsinki.fi/ bitstream/handle/10138/161704/PaloMarjaProGradu.pdf?sequence=2\&isAllowed=y.

Paulaharju, S. 1928. Ruijan suomalaisia. Helsinki: Kustannusosakeyhtiö Kirja.

Paulaharju, S. 1935. Ruijan äärimmäisillä saarilla. Porvoo: Werner Söderström.

Paunonen, H. 2018. Tornion murteesta meänkieleen. Reaaliaikainen tutkimus Ruotsin Ylitorniolta 1966-1992. Teoksessa S. Brunni, N. Kunnas, S. Palviainen \& J. Sivonen (toim.) Kuinka mahottomasti nää tekkiit. Juhlakirja Harri Mantilan 60-vuotispäivän kunniaksi. Studia humaniora ouluensia 16. Oulu: Oulun yliopisto, 15-161.

Pauwels, A. 2016. Language maintenance and shift. Cambridge: Cambridge University Press.

Pennycook, A. 2017. Language Policy and Local Practises. Teoksessa O. Garcia, N. Flores \& M. Spotti (toim.) Oxford Handbook of Language and Society. Oxford: Oxford University Press, 130-147.

Pulkkinen, P. 1972. Nykysuomen kehitys. Katsaus 1800-ja 1900-luvun kirjakieleen sekä tekstinäytteitä. Helsinki: Suomalaisen Kirjallisuuden Seura.

Raittila, P. 1967. Lestadiolaisuuden matrikkeli ja bibliografia. Helsinki: Suomen kirkkohistoriallinen seura.

Rasmussen, S. 2011. Prester og prestefruer i Kautokeino pastorat. Ottar, 286 (3), 62-69.

Ryymin, T. 2004. «De nordligste finner.» Fremstillingen av kvenene i den finske litterære offentligheten 1800-1939. Speculum Boreale 6. Tromsø: Universitetet i Tromsø.

Sainio, M. A. 1949. Norjassa ilmestyneet suomenkieliset painotuotteet. Finske skrifter trykt $i$ Norge. Turun yliopiston kirjaston julkaisuja 5. Turku:Turun yliopiston kirjasto.

Tiililä, O. 1961. Rukoilevaisten kirjoja. Helsinki: Suomalaisen Kirjallisuuden Seura.

Tommila, P. 1986. Lukutaidon yleistyminen Suomessa. Teoksessa Album amicorum. Kirjaja kulttuurihistoriallisia tutkielmia Eeva Mäkelä-Henrikssonille 29.7.1986. Helsinki: Helsingin yliopiston kirjasto, 175-181.

Tommila, P. \& R. Salokangas 2000. Tidningar för alla. Den finländska pressens historia. Göteborg: NORDICOM. 
Udir.no 2015. Kvener/norskfinner. https://www.udir.no/globalassets/filer/laringsmiljo/ nasjonale minoriteter/nasjonale_minoriteter_kvener_norskfinner.pdf.

Vallinkoski, J. \& H. Schauman (toim.) 1986. Suomen historiallinen bibliografia

1544-1900. 2. painos. Jyväskylä: Suomen historiallinen seura.

http://www.doria.fi/bitstream/handle/10024/162492/KK005_opt. pdf;jsessionid=299244BA62831120B893C49C7889A5E0? sequence $=1$.

Varpio, Y. 1997. Matkalla moderniin Suomeen. 1800-luvun suomalainen matkakirjallisuus. Helsinki: Suomalaisen Kirjallisuuden Seura.

Vikman, K. O. 1910. Suomen kansan lukutaidon synty ja kehitys Ruotsin vallan aikana. Helsinki: Suomalaisen kansan kirjapaino.

Vuolasto, J. 2011. Pietismin kuva - ikkuna yksityiseen hengellisyyteen: Johann Arndtin opetukset pietistisen embleemin perustana. Kouvola: Kopijyvä. https://helda.helsinki.fi/ handle/10138/26181.

Välitalo, P. 1970. Muonionlaakson kylärukouksista. Teoksessa V. Arrela \& Y. Alamäki (toim.) Tornionlaakson vuosikirja. Tornionlaakson kotiseututoimikunta: Tornio, 20-35.

Weihe, H. J. W. 2018. Thomas von Westen. Teoksessa Store norske leksikon. https://snl.no. [Luettu 11.6.2019.]. 